\title{
Influence of environmental factors on the presence of Vibrio cholerae in the marine environment: a climate link
}

\author{
Violeta Trinidad Pardío Sedas \\ Facultad de Medicina Veterinaria y Zootecnia, Universidad Veracruzana, Apartado Postal 1380, Veracruz, \\ Veracruz, CP. 91700, México.
}

\begin{abstract}
Evidence indicates that the atmospheric and oceanic processes that occur in response to increased greenhouse gases in the broad-scale climate system may already be changing the ecology of infectious diseases. Recent studies have shown that climate also influences the abundance and ecology of pathogens, and the links between pathogens and changing ocean conditions, including human diseases such as cholera. Vibrio cholerae is well recognized as being responsible for significant mortality and economic loss in developing countries, most often centered in tropical areas of the world. Within the marine environment, $V$. cholerae is found attached to surfaces provided by plants, filamentous green algae, copepods, crustaceans, and insects. The specific environmental changes that amplified plankton and associated bacterial proliferation and govern the location and timing of plankton blooms have been elucidated. Several studies have demonstrated that environmental non-O1 and non-0139 V. cholerae strains and V. cholerae O1 El Tor and $\mathrm{O} 139$ are able to form a three-dimensional biofilm on surfaces which provides a microenvironment, facilitating environmental persistence within natural aquatic habitats during interepidemic periods. Revealing the influence of climatic/environmental factors in seasonal patterns is critical to understanding temporal variability of cholera at longer time scales to improve disease forecasting. From an applied perspective, clarifying the mechanisms that link seasonal environmental changes to diseases' dynamics will aid in developing strategies for controlling diseases across a range of human and natural systems.

Key Words: Vibrio cholerae, environmental factors, climate change, temporal variability.
\end{abstract}

J Infect Developing Countries 2007; 1(3):224-241.

Received 4 June 2007 - Accepted 17 October 2007.

Copyright (C) 2007 Pardío Sedas. This is an open access article distributed under the Creative Commons Attribution License, which permits unrestricted use, distribution, and reproduction in any medium, provided the original work is properly cited.

\section{Introduction}

Anthropogenic climate change is measurably affecting ecosystems, communities, and populations [1]. Diverse environmental factors influence the distribution, diversity, incidence, severity, and/or persistence of diseases and other health issues - something that has been recognized for millennia [2]. Health and climate have been linked since antiquity. In the fifth century B.C., Hippocrates observed that many specific human illnesses were linked to changes of season, local weather patterns, and other environmental factors such as temperature [3].

The reality of climate change and the associated role of anthropogenic activity are being debated in many forums. Human activities may have impacts on ecological balances, potentially leading to new diseases associated with environmental changes such as temperature extremes and violent weather events (e.g. fewer frosts and more storms, floods, and droughts; abnormal seasonal conditions associated with increases in temperature or moisture).

Climate change and variability have led to growing concerns regarding the effects of climate on health. The combination of climate change and environmental degradation has created ideal conditions for the emergence, resurgence and spread of infectious diseases, killing millions of people annually [2]. In a quantitative climate-health assessment study, the World Health Organization (WHO) examined the global burden of disease attributable to anthropogenic climate change up to the year 2000 [4]. This study indicated that the climatic changes that have occurred since the mid1970s could already have caused over 150,000 deaths and approximately five million "disabilityadjusted life years" (DALYs) per year through diseases such as diarrhoea (temperature effects only), malaria, and malnutrition, mainly in developing countries [5]. 
Many factors, such as human behavior, public health infrastructure, food production, microbial adaptation and environmental change, have contributed to the persistence and increase in the occurrence of infectious diseases. An important risk of climate change is its potential impact on the evolution and emergence of infectious disease agents. Ecosystem instabilities brought about by climate change and concurrent stresses such as land use changes, species dislocation, and increasing global travel could potentially influence the genetics of pathogenic microbes through mutation and horizontal gene transfer, giving rise to new interactions among hosts and disease agents. The disease agents and their vectors each have particular environments that are optimal for growth, survival, transport, and dissemination [6].

Vibrio cholerae is well recognized as the causative agent of the human intestinal disease cholera, which is responsible for significant mortality and economic loss in underdeveloped countries, most often centered in tropical areas of the world. Generally, V. cholerae is transmitted through contaminated food and water in communities that do not have access to proper sewage and water treatment systems [7], and is thus called "the disease of poverty" [8].

Cholera provides one of the best examples of how an emerging infectious disease has evolved from an oral-fecal transmission linear model of a waterborne bacterium and a human host, to a more complex ecological model of an infectious disease. During the last three decades, extensive research has been conducted to explain the virulence properties and the epidemiology of this pathogen. Recently, researchers have also been investigating the environmental lifestyle of $V$. cholerae, and ecologically based models have been developed to define the role of environment, weather, and climate-related variables in outbreaks of this disease. These models include global weather patterns, the deep sea, aquatic reservoirs, zooplankton, the collective behavior of surface attached cells, and an adaptable genome, together with the bacterium and its host [9-11].

This review provides current evidence for the influence of environmental factors on Vibrio cholerae dynamics and virulence traits of this organism. A better understanding of disease risk related to the environment should call attention to the urgent need for action to prevent the consequences of climate change and to improve the socioeconomic conditions contributing to cholera.

\section{Climate change, Health and Infectious Diseases}

Accelerated climate change and variability are already influencing the functioning of many ecosystems, the seasonal cycles and geographic range of communities and populations, destabilizing biological control of infectious diseases, and affecting food production and water availability. These ecological changes strongly influence disease patterns as an unstable climate is playing an ever-increasing role in driving the global emergence, resurgence and redistribution of infectious diseases [12] and their health impact on human populations. Tropical climate, poor water and food security, low socio-economic status and political instability define the regions most vulnerable to the health effects of climate change [13].

Global climate change is conceived as manifesting itself in each of three interrelated modules: changes in transmission biology, ecologic changes, and sociologic changes. Chan et al. (1999) [14] developed an integrated assessment framework (IAF) for climate change and infectious diseases (Fig. 1). These modules impact epidemiologic outcomes, including mortality and morbidity rates. Any effects of climate change will probably operate on the groups of factors in different ways and will likely be nonlinear, region specific, and time dependent. Most models developed for climate-sensitive health determinants and outcomes provide global or large regional estimates of changes in risk associated with climate change.

Three broad categories of health impacts are associated with climatic conditions depending on the direct impact of extremes in local weather conditions: impacts directly related to weather and climate variability; impacts resulting from environmental changes that occur in response to climate variability and change; and impacts resulting from consequences of climate-induced economic dislocation and environmental decline. There are two categories of climate-sensitive health determinants and outcomes. The first category includes changes in the frequency and intensity of thermal extremes, and extreme 
weather events (floods and droughts) that directly affect population health. This category includes impacts such as deaths, injuries, psychological disorders, and exposure to thermal extremes that alters rates of illness and death related to heat and cold. The second category includes indirect impacts that occur through changes in the geographic range and intensity of transmission of infectious diseases; changes in the geographic range and intensity of transmission of in food- and waterborne diseases; and changes in the prevalence of adverse health outcomes associated with air pollutants and aeroallergens. The indirect effects of this category include changes in local ecology of waterborne agents that modify the incidence of diarrhea and other infectious disease and food-borne infective agents, and alterations on range and activity of vectors that change geographical ranges and infective parasites and incidence of vector-borne disease. Estimating the consequences of indirect effects poses a challenge because those impacts typically result from changes in complex processes. They include alterations in the transmission of vector-borne infectious disease, alterations in water quality and quantity, and changes in the productivity of agroecosystems, with the potential for displacement of vulnerable populations as a result of local declines in food supply or sea level rise. There is a range of estimates of the risk of hunger reflecting different assumptions about future growth of populations, international trade, and adaptive agricultural technology. Such estimates, however, do not include the likely additional influence of extreme weather events or of increases in agricultural pests and pathogens $[15,16,17]$.

Studies of climatic influences on infectious diseases have mainly focused on the influence of El Niño-Southern Oscillation (ENSO), that has been found to be related to incidences of malaria in South America, rift valley fever in east Africa, dengue fever in Thailand, hantavirus pulmonary syndrome in the southwestern USA, and childhood diarrhoeal disease in Peru. It is unclear at this stage whether global climate change will significantly increase the amplitude of ENSO variability, but if so, the regions surrounding the Pacific and Indian oceans are expected to be most vulnerable to the associated changes in health risks. Cholera provides another instructive example. The ancestral home of cholera was apparently the Ganges delta, in India, where epidemics of a cholera-like disease have been described over the past four centuries. The most recent cholera pandemic (the seventh cholera pandemic) has reached further than ever before, affecting Asia, Europe, Africa, North America and Latin America. It began in 1961 and is by far the longest lasting pandemic to date. The extraordinary scale and persistence of this pandemic is thought largely to reflect the escalation in nutrient enrichment of coastal and estuarine waters by phosphates and nitrates in run-off wastewater, and the proliferation of urban slums without access to safe drinking water [5].

Figure 1. Integrated assessment framework for evaluating the association between climate change and infectious diseases (reproduced from Chan et al., 1999)
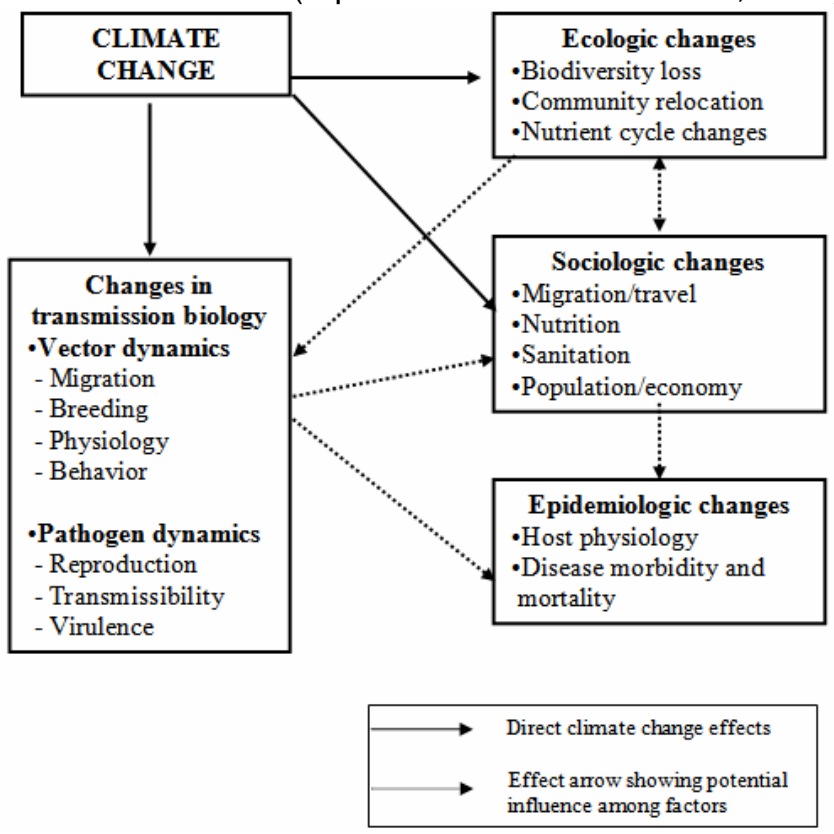

Several disease categories have been listed along with specific examples of diseases that had known or suspected relationships with weatherrelated variables [18]:

- Airborne: influenza, meningococcal meningitis, coccidiodomycosis, respiratory syncytial virus (colds).

- Vector-borne: malaria, dengue, encephalitis, ehrlichiosis, leishmaniasis

- Water and food-borne: cholera, Vibrio parahaemolitycus, V. vulnificus, leptospirosis, human enteric viruses (enteroviruses, Norwalk and Norwalk-like 
viruses), salmonellosis, shigellosis, campylobacteriosis, and over 30 species of parasites that infect the human intestines. Seven of these are distributed globally or cause serious illness: ameobiasis, giardiasis, Taenia solium taeniasis, ascariasis, hookworm, trichuriasis, and strongyloidiasis.

Understanding links between infectious disease and climate is difficult, given the multivariate nature of climate change, and nonlinear thresholds in both disease and climate processes. In order to relate environmental factors directly to disease or probability of infection, it is necessary to define the environmental factors related directly to the pathogen, and then to evaluate the influence of environmental factors in the concentration, distribution, prevalence, viability and virulence of the pathogen and the disease outcome. As an example, it has been reported that climate warming can affect host-pathogen interactions by increasing pathogen development rates, transmission, and number of generations per year, relaxing overwintering restrictions on pathogen life cycles, modifying host susceptibility to infection [19]. Not all infectious diseases are influenced by climate or weather variability. Vectorborne diseases were the first and most often to be associated with climate related variables [18].

\section{Climate and Waterborne diseases}

Globally waterborne diseases are one of the major contributors to disease burden and mortality [20]. Water-related diseases are typically placed in four classes: waterborne, water-washed, waterbased, and water-related insect vectors. The first three are most clearly associated with lack of improved domestic water supply. Waterborne diseases are spread through drinking water contaminated by human or animal faeces or urine containing pathogenic bacteria or viruses; exposure to contaminated water while swimming or other activities; or secondarily through food contaminated with bad water. Waterborne diseases include cholera, typhoid, amoebic and bacillary dysentery, and other diarrhoeal diseases [18,21].

All of these transmission patterns may be affected by climate variability and thus potentially by climate change. Weather is often a factor in triggering waterborne disease outbreaks. If weather is a determinant of waterborne disease outbreaks, it is likely also a contributing factor to endemic cases of disease. Thus, the impact of heavy rainfall on waterborne illness may be widespread [22]. A major US study by Curriero et al. (2001) [23] reported a statistically significant association between excess rainfall and waterborne disease outbreaks over a long period of time and on a national scale. The study, based on 548 reported outbreaks in the United States from 1948 through 1994, was able to quantify the relationship between excessive rainfall and disease outbreaks. The study analyzed the relationship between rainfall and waterborne disease on a watershed level, stratified the outbreaks by groundwater and surface water contamination, and controlled for effects due to season and hydrologic region. The results indicated that $51 \%$ of waterborne disease outbreaks were preceded by rainfall events above the 90th percentile and that $68 \%$ were preceded by events above the 80th percentile. Outbreaks due to surface-water contamination showed the strongest association with excessive rainfall during the month of the outbreak. Groundwater contamination events were preceded by a 2-month lag in rainfall accumulations.

For many waterborne diseases, the management and disposal of sewage, biosolids and other animal wastes, and the protection of watersheds and fresh water flows are critical variables that impact water quality and the risk of waterborne disease. Water-related diseases are a particular problem in poor countries and communities, where water supplies and sanitation often are inadequate. Many communities in developing countries continue to use combined sewer and storm water drainage systems; these may pose a health risk should the frequency or intensity of storms increase, because raw sewage bypasses treatment and is discharged into receiving surface waters during storms $[19,24]$.

Major disturbances involving microorganisms began to occur more frequently in the mid-1970s, particularly between 1972 and 1976, which coincides with a relatively abrupt shift in the global climate regime. In order to explain disease emergence in the oceans, various processes have been invoked including warming of the earth's atmosphere, increased ultraviolet (UV) radiation 
resulting from ozone depletion, and intensified pressures relating to anthropogenic impacts such as overexploitation of fish and other higher trophiclevel organisms, marine pollution, coastal eutrophication, oxygen depletion and sedimentation. Nevertheless, functional linkages and mechanistic relationships have not been established between the parameters of change (temperature, UV radiation, macronutrients, water chemistry) and the nature of outbreak responses (frequency, intensity, species diversity) [25].

Oceanic and coastal waters are known to harbor and transport microorganisms that cause disease in humans and animals. As modulators of climate, oceans also indirectly influence disease patterns and distribution of many pathogens. While certain pathogenic or toxigenic microorganisms, including toxic phytoplankton and Vibrio spp. occur naturally in marine and estuarine waters, anthropogenic contaminants including enteric bacteria, protozoa and viruses may be introduced to coastal waters as sewage pollution. Despite the relatively unfavorable environment, these introduced organisms may survive for prolonged periods in the marine environment, often associated with sediments and other protective environments [18]. The main mechanisms for regulation of bacterial populations in the aquatic environment include availability of nutrients, temperature, bacterivory, and lysis by viruses, with nutrient availability being the most important factor in limiting the size and abundance of bacterial populations. In eutrophic habitats of coastal ocean, estuary, and freshwater ecosystems, bacterial abundance, production, and growth rates are regulated by physical and chemical factors in addition to nutrient availability [26].

The current evidence of the impact of climate on the epidemiology of waterborne disease is considered under the following headings: the impact of heavy rainfall events, the decrease in salinity, the increase in sea level and subsequent changes in ocean circulation, the impact of flooding, and the impact of increased temperature (Fig. 2).

The following environmental factors influence, either directly or indirectly, the survival of bacterial populations and their ability to produce disease: (i) temperature, where greater inactivation/death rates occur at higher temperatures; (ii) sunlight, which can affect the persistence and spread of a pathogen if it is associated with phytoplankton and/or algae; (iii) sunlight (UV), in which nucleic acids absorb the UV energy and are damaged; (iv) humidity, resulting from evaporation due to elevation of temperature; (v) moisture content, where low moisture inactivates/kills some microbes; (vi) $\mathrm{pH}$, in which extreme $\mathrm{pH}$ inactivates microbes with important exceptions such as enteric pathogens which survive at $\mathrm{pH}$ 3.0; (vii) weather, where warmer weather increases some microbes and wet weather carries microbes also resuspended in water resources; (viii) chemicals and nutrients as their levels influence microbe survival, in which lack of nutrients (e.g. carbon, nitrogen) will limit proliferation; (ix) biological factors such as attachment of bacteria to a hostspecific or site-specific location before they can multiply (the factors that influence attachment include temperature, $\mathrm{pH}$, and nutrient concentration); (x) rainfall, where heavy rainfall may lead to changes in the direction of flow of water systems and for surface water sources, heavy rainfall can lead to overflow of storm drains that may be combined with the sewage system, allowing faecally polluted water into rivers; and (xi) flooding, in developing nations where there is evidence of outbreaks following floods caused by heavy rains which may eliminate the habitat for both vectors and vertebrate hosts $[6,24]$.

For example, in developing countries located in tropical and subtropical regions with crowding and poverty, heavy rainfall and flooding may trigger outbreaks of diarrhea [27]. Each of these climatic factors can have markedly different impacts on the epidemiology of various waterborne diseases [28].

\section{Environmental Factors Influencing Survival or Proliferation of $\boldsymbol{V}$. cholerae}

Recent studies have shown that climate also influences the abundance and ecology of pathogens, as well as the links between pathogens and changing ocean conditions, including human diseases such as cholera $[19,29]$. Vibrio cholerae is a motile, Gram-negative curved rod that belongs to the family Vibrionaceae, and is a well-known human pathogen that has caused cholera epidemics worldwide and continues to be prevalent in many developing countries $[7,30]$, with serious epidemics often localized in tropical areas [31]. With the apparent increase in its emergence, cholera is, at present, one of the most important of 
the resurgent diseases [32,33]. In South America, outbreaks start along the coast [34], and epidemiological studies in México have demonstrated that people living in coastal states are at a high risk of contracting the disease, as shown in Fig. 3 [35].

Figure 2. Potential waterborne and foodborne diseases.

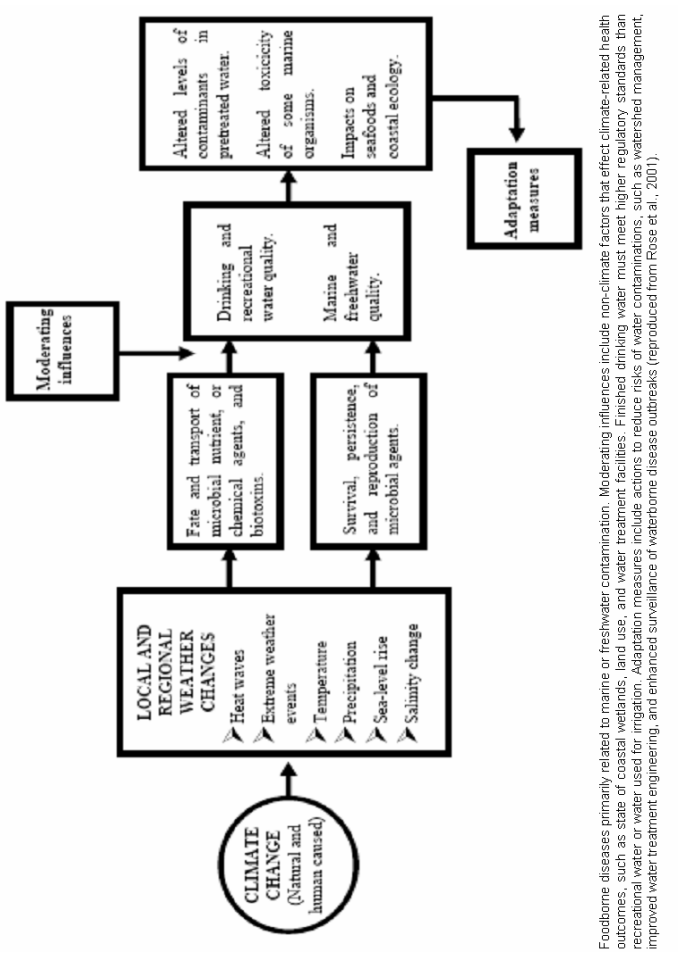

Figure 3. Cholera incidence in States of México (reproduced from Borroto and Martínez-Piedra, 2000).

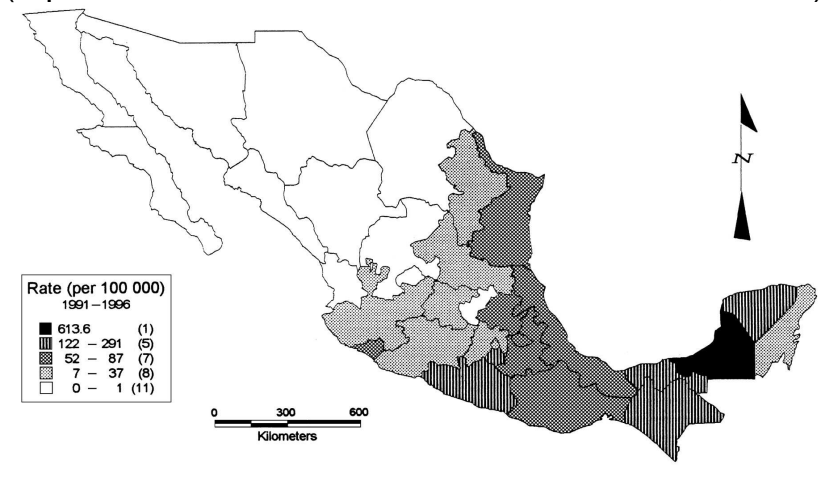

Genus Vibrio includes Gram-negative bacteria indigenous to marine and estuarine waters, and facultative anaerobic, non-spore forming bacilli which are oxidase-positive and halophilic. Furthermore, $V$. cholerae is an autochthonous microbial inhabitant of brackish water, estuarine ecosystems, and coastal areas; the species can remain in a culturable state in the marine environment for years [36]. $V$. cholerae can pose a public health risk when it is ingested via untreated water, contaminated seafood (raw or undercooked), or exposure of skin wounds to sea water [37-40].

The prevalence of pathogenic Vibrios appears to be influenced by the physico-chemical features of the environment; studies in coastal and estuarine regions of different parts of the world have highlighted the potential significance of environmental factors to the dynamics of the disease. Previous studies of cholera population dynamics have proposed links between climate, oceanographic environmental conditions such as temperature, phytoplankton productivity, and human cases of cholera morbidity and mortality. It has been reported that climate may affect the dynamics of cholera by shifting pathogen or host reservoir species abundance, population dynamics, and community interactions [41-42]. Nevertheless, the mechanistic basis for climatecholera connection remains scantily understood. The environmental and climate factors that have been associated with $V$. cholerae are presented in Table 1.

Table 1. Influence of environment, climate, and weather on cholera and $V$. cholerae dynamics (Lipp et al., 2002) [19].

\begin{tabular}{|c|c|c|}
\hline Factor & $\begin{array}{c}\text { Climate and } \\
\text { Weather Drivers }\end{array}$ & Influence(s) \\
\hline Temperature & $\begin{array}{c}\text { Seasons, interannual } \\
\text { variability }\end{array}$ & $\begin{array}{c}\text { Growth of } V \text {. } \\
\text { cholerae, } \\
\text { phytoplankton } \\
\text { blooms, infection by } \\
\text { temperate phages }\end{array}$ \\
\hline Salinity & $\begin{array}{l}\text { Seasons, monsoons, } \\
\text { ENSO, sea level rise }\end{array}$ & $\begin{array}{l}\text { Growth of } V \text {. } \\
\text { cholerae, } \\
\text { seroconversion, } \\
\text { expression of } \\
\text { cholera toxin }\end{array}$ \\
\hline Sunlight & $\begin{array}{l}\text { Seasons, monsoons, } \\
\text { interannual variability }\end{array}$ & \\
\hline $\mathrm{pH}$ & $\begin{array}{c}\text { Seasons, interannual } \\
\text { variability } \\
\text { (phytoplankton } \\
\text { growth) }\end{array}$ & $\begin{array}{c}\text { Growth of } V . \\
\text { cholerae }\end{array}$ \\
\hline Fe3+ & $\begin{array}{c}\text { Precipitation (runoff), } \\
\text { atmospheric } \\
\text { deposition (NAO) }\end{array}$ & $\begin{array}{c}\text { Growth of } V \text {. } \\
\text { cholerae, expression } \\
\text { of } \\
\text { cholera toxin }\end{array}$ \\
\hline $\begin{array}{l}\text { Exogenous products } \\
\text { of algal growth }\end{array}$ & $\begin{array}{c}\text { Seasons, monsoons, } \\
\text { interannual variability } \\
\text { in light, nutrients }\end{array}$ & $\begin{array}{c}\text { Survival of } V . \\
\text { cholerae }\end{array}$ \\
\hline Chitin & $\begin{array}{c}\text { Seasons, monsoons, } \\
\text { zooplankton blooms } \\
\text { (following } \\
\text { phytoplankton) }\end{array}$ & $\begin{array}{c}\text { Growth of } V \text {. } \\
\text { cholerae, attachment } \\
\text { to } \\
\text { exoskeletons }\end{array}$ \\
\hline
\end{tabular}


Two of the primary environmental variables influencing this complex ecology of pathogenic Vibrios are temperature and salinity which, along with sea surface temperature (SST), is consistent with the role played by sea surface height [29] in combination with elevated $\mathrm{pH}$. The optimum temperature for growth of this organism is $37^{\circ} \mathrm{C}$, with possibilities for growth ranging from 16 to $42^{\circ} \mathrm{C}[36]$.

Temperature and salinity play roles in the occurrence of $V$. cholerae in the aquatic environment [43-45]. Vibrios are present in the environment even when they cannot be cultured. $V$. cholerae can survive under unfavorable environmental conditions in a dormant state, switching into a viable-but-non-culturable (VBNC) state in response to rapid transitions in environmental conditions such as temperature and osmolarity, and nutrient deprivation. When $V$. cholerae enters the viable-but-non-culturable state, it loses its flagellum and changes to a smaller, spherical form, in a spore-like stage [46-48]. This dormant state serves as a survival strategy as cells survive changes in temperature, salinity, or availability of organic matter and remain infectious [36].

Franco et al. (1997) [49] provided evidence for a positive association between counts of the pathogen $V$. cholerae and river water temperature two months earlier in Perú. The influence of temperature on the timing of the pathogen's appearance was demonstrated with the presence or absence of CT-positive V. cholerae. In addition, the number of cholera cases correlated significantly $(r=0.72)$ with CT-positive cholera counts at cleaner sites upriver two to three months earlier, supporting a role of water temperature in its seasonality. Barbieri et al. (1999) [44] observed a positive correlation $\left(r^{2}=0.559, P=0.038\right)$ between the occurrence of Vibrio spp. and temperature in two estuaries along the Italian Adriatic Coast. Pascual et al. (2000) [11] conducted a time-series analysis of an 18-year cholera record from Bangladesh and reported a positive effect of El Niño-Southern Oscillation (ENSO), a major cause of interannual climate variability, on the predictions of cholera incidence in the fall. Their results suggested that higher ambient temperatures would correspond to higher water temperatures in shallow bodies of water, such as ponds and rivers in estuaries, and shallow coastal waters, increasing local temperature and producing the interannual variability of cholera. Lobitz et al. (2000) [10] used satellite data to monitor the timing and spread of cholera. The remote sensing data included sea surface temperature (SST) and sea surface height (SSH). They discovered that SST shows an annual cycle similar to the cholera case data (Fig. 4). The warming of water temperature in ponds and rivers might increase the incidence of cholera through the faster growth rate of the pathogen in aquatic environments.

Figure 4. Remote Sensing of Cholera: 1994 SST and Cholera Plot.

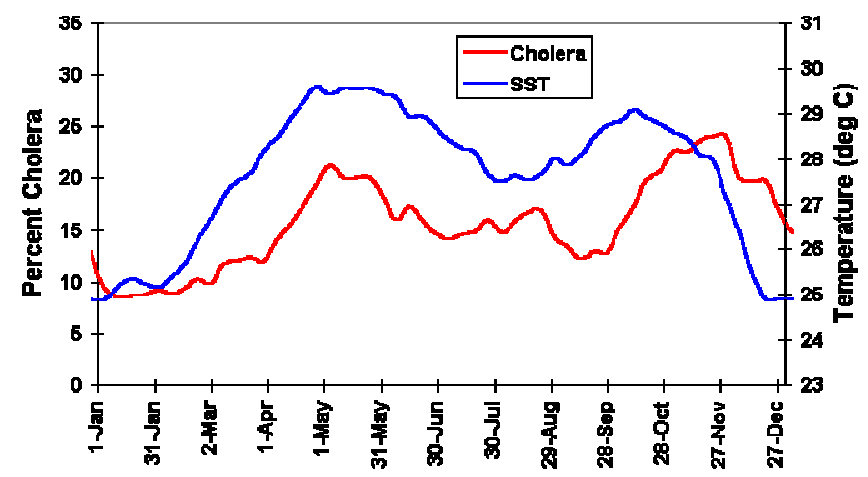

Cholera case data in Bangladesh followed sea surface temperatures (SST) in 1994. The SST had an annual cycle similar to the one shown here every year, while the cholera case data did not show a clear pattern. The SST cycle can also be seen in the time series for 1992 did not show a clear pattern. The SST cycle can also be seen in the time series for 1992. the SST in June through August. Coastal processes are very complex. Without examining the relationship between plankton data and cholera, the link between SST, plankton, and cholera outbreaks cannot be determined (reproduced form Lobitz et al., 2000).

Barnett et al. (2001) [50] reported the warming of the ocean since 1950. The Panel on Climate Change (IPCC) [51-53] has projected an increase in world average temperature of $1.0^{\circ} \mathrm{C}-3.5^{\circ} \mathrm{C}$ by the year 2100, and an associated rise in sea level of $50 \mathrm{~cm}$ is also expected by the 2080s, with considerable regional variations. As a result of warming seawater, the world oceans are expanding. Coupled with freshwater input from icemelt, thermal expansion of the oceans is causing sea levels to rise at c. $2 \mathrm{~mm}_{\text {year }}{ }^{-1}$. This assessment is derived from projections made by computer-based global climate models that combine, through simultaneous equations within a 3-dimensional global grid, the atmospheric and oceanic processes that occur in response to increased greenhouse gases and the resulting rise in radiative forcing in the lower atmosphere [15]. Evidence is indicating that these changes in the broad-scale climate system may already be 
changing the ecology of infectious diseases [5455].

Heidelberg et al. (2002) [26] reported an increase of $V$. cholerae in water samples collected from the Choptank River in Chesapeake Bay during summer months, associated with an increase in water temperature $\left(r^{2}=0.420,-0.720\right)$ as Louis et al. (2003) [56] reported. According to Rodó et al. (2002) [57], enhanced warming can also affect disease transmission by changing human behavior, with a possible increase in the contact with contaminated water sources under warm conditions immediately before and during the spring, when the first seasonal peak in cholera is typically observed. According to these authors, the effect of more extreme ENSO and climate changing conditions of drought and flood remain to be examined, but are consistent with future global and regional scenarios that also might impact sanitation conditions critical to cholera transmission. A remarkable finding from a study by Huq et al. (2005) [58] was that water temperature was directly correlated with cases of cholera in Bakerganj, the southernmost site included in the study, having the most direct influence from the Bay of Bengal, where most of the initial cases of cholera occurred, including the outbreak of newly recognized serotype O139 in 1992.

Another adaptive feature allows $V$. cholerae to survive for prolonged periods when soluble iron is unavailable; $V$. cholerae can produce ironchelating siderophores to take up insoluble iron from the environment. Survival is thus further improved when insoluble iron $\left(\mathrm{Fe}_{2} \mathrm{O}_{3}\right)$ is available in an alkaline $\mathrm{pH}$ environment, as $\mathrm{V}$. cholerae also thrives under high-pH conditions. Environmental conditions may also affect expression of virulence genes in $V$. cholerae. Sunlight can induce propagation of the CTX_phage, and the viability of $V$. cholerae remains stable in full sunlight compared to enteric bacteria such as $E$. coli, which may impart some selective advantage to vibrios at tropical latitudes. Furthermore, moderate levels of introduced iron also increase the expression of CT. Therefore, environmental triggers may become epidemiologically important for the prevalence of the organism and its virulence (potentially resulting in shorter onset times and lower infectious doses) [29].

In our work [59], $V$. cholerae non-O1 occurrence in water samples correlated with water temperature $\left(r^{2}=0.468, P<0.05\right)$ and $V$. cholerae O1 Inaba occurrence in La Mancha lagoon oysters correlated $\quad\left(r^{2}=0.543, \quad P<0.05\right) \quad$ with water temperature averaging $>30^{\circ} \mathrm{C}$. Our results indicate that seasonal salinity variability and warm temperatures, as well as nutrient influx, may influence the occurrence of $V$. cholera non-O1 and 01. The conditions found in the Alvarado $\left(31.12^{\circ} \mathrm{C}, 6.27 \mathrm{psu}, \mathrm{pH} 8.74\right)$ and La Mancha lagoons $\left(31.38^{\circ} \mathrm{C}, 24.18 \mathrm{psu}, \mathrm{pH} 9.15\right)$ during the rainy season in 2002 favored the occurrence of $V$. cholera 01 Inaba enterotoxin positive traced in oysters, indicating that environmental conditions could also affect expression of virulence genes in $V$. cholerae. Mahasneh y Al-Sayed (1997) [60] isolated both $V$. cholerae and $V$. parahaemolyticus in seawater and oysters (Pinctada radiata) during the warmer months (June, July, September and October 1992). In oysters, V. cholerae was more prominent than $V$. parahaemolyticus. Peak counts in oysters at nearshore and pelagic sites occurred in July and they were five times greater at the pelagic site. In general, most bacteria were isolated from the pelagic waters and oyster samples, and they were highest during the warmer months. Some disappeared totally during February and March. Water temperature was found to have greater influence on the distribution of different bacteria in water and oysters, compared with other environmental factors.

Salinities favorable for $V$. cholerae growth are found primarily in inland coastal areas and estuaries, but survival of $V$. cholerae in seawater for more than 50 days has been demonstrated [61]. Pathogenic $V$. cholerae grows in water with low salinity if the water temperature is relatively high and organic nutrients are present even in small concentrations (less than $1 \mathrm{mg} / \mathrm{L}$ ), compensating, to a degree, for lack of salt $[36,43]$. Although optimal salinity for $V$. cholerae growth is between 5 and 25 psu, $V$. cholerae can tolerate salinities near 45 psu [62]. In our work [59] we reported that water temperature and salinity were significantly associated $(P<0.05)$. $V$. cholerae nonO1 percent isolation in oysters correlated with $\mathrm{La}$ Mancha lagoon water temperature and salinity $\left(r^{2}=0.603, P<0.05\right)$ and Alvarado lagoon water temperature and salinity correlated with $V$. cholerae non-O1 isolation in oyster samples $\left(r^{2}=0.576, P<0.05\right)$. 
Other climatic variables related to water levels such as rainfall have also been invoked to explain cholera patterns since early times. Floods and droughts can affect not only the concentration of the bacterium in the environment, but its survival through the effect of salinity, $\mathrm{pH}$ or nutrient concentrations, as well as human exposure to the pathogen, sanitary conditions and susceptibility to disease.

Chlorophyll a and/or turbidity have been associated with rainfall events; influence of rainfall and runoff on salinity and nutrients leading to algal blooms; influence of phytoplankton on zooplankton dynamics and succession; influence of temperature and salinity on the growth of Vibrio in the copepod; concentration of the bacteria in the copepod; and numbers of copepods transmitted upstream and in a glass of water [63-64].

Floods and droughts may affect not only the concentration of the bacterium in the environment, but also its survival, through the effect exerted by these environmental changes on salinity, sunlight, $\mathrm{pH}$, and nutrient concentrations [36,65-68]. In addition, water temperature would drive seasonality by direct influence on the abundance and/or toxicity of $V$. cholerae in the environment, or alternatively, through their indirect influence on other aquatic organisms such as zooplankton (Copepods - Acartia, Cyclops, Diaptomus, Cladocerans - Daphnia, Bosmina, Bosminopsis, Ceriodaphnia, Diaphanosoma, rotifers), phytoplankton (Cyanobacteria - Anabaena, Chlorophytes - Volvox, desmids, Rhizoclonium, Diatoms - Skeletonema, Dinoflagellates), macrophytes (Marine taxa - Ulva, Entermorpha, Ceramium, Polysiphonia, Freshwater taxa Eichhornia (water hyacinth), Lemna (duckweed), Benthos (Prawns - Penaeus, Metapenaeus, Macrobrachium, oysters, crabs, chironomid egg masses), and fish (Sea mullet) to which the pathogen is found attached [36,65]. Within the marine environment, $V$. cholerae is found attached to surfaces provided by plants, filamentous green algae, copepods (zooplankton), crustaceans, and insects [69-70]. Many pathogenic Vibrio spp. are associated with chitinaceous zooplankton and shellfish, and can survive on fish and shellfish as well [71]. Shellfish feeding on planktonic crustaceans are colonized by $V$. cholerae in natural water systems [69,72-75]. Vibrio cholerae survive in association with aquatic vegetation, as well as other zooplankton and crustacean invertebrates in the aquatic environment [65-76]. After concentration by filter-feeding shellfish such as oysters, these bacteria may be present at concentrations that are 100-fold higher than those in the surrounding water [77-78].

The algae and zooplankton that feed upon them provide a natural refuge for Vibrio cholerae, where, under normal conditions, the bacteria exist in a non-culturable state for long periods. The Vibrios appear to enter a non-culturable phase induced primarily by unfavorable conditions such as low temperature [79]. An increase in sea surface temperature, along with high nutrient levels (eutrophication) that stimulate algal growth and deplete oxygen, can activate the blooms and in turn, lead to increased numbers of Vibrios [28]. The culturability of $V$. cholerae remains stable in full sunlight compared to enteric bacteria such as E. coli, which may impart some selective advantage to Vibrios at tropical latitudes [80].

Due to the relationship between zooplankton and phytoplankton populations, dynamics between climate and phytoplankton, although indirect, are important mechanisms that regulate the prevalence of the bacteria in the environment. The specific environmental changes that amplify plankton and associated bacterial proliferation and govern the location and timing of plankton blooms, are nutrient levels, SST and solar radiation [29], $\mathrm{pH}$, currents, winds, and river runoffs [81]; tidal forces and other physical processes can affect phytoplankton growth through the transport of deep nutrient-loaded water to the surface; however, heavy precipitation can dilute nutrient levels and decrease phytoplankton production [64]. Attachment, growth, and multiplication of $V$. cholerae in the aquatic environment, particularly in association with copepods, are influenced by warmer temperatures, elevated $\mathrm{pH}$ (8.5), salinity (between 5 and 25 psu), and plankton blooms which are, in turn, controlled by large-scale climate variability $[29,56,81]$.

The correlation of cholera outbreaks and the seasonal occurrence of algal blooms has been reported $[36,63,73]$; however, there is no direct evidence that such events lead to an enrichment of toxigenic $V$. cholerae strains responsible for cholera epidemics. Because many phyto- and zooplankton organisms may serve as reservoirs for the cholera bacterium $[36,71,73-75]$, disease 
outbreaks in humans may be strongly correlated with the population and community dynamics of these hosts $[10,29,82]$. The appearance of cholera cases in coastal human communities correlated with variations in phyto- and zooplankton abundance in the marine environment induced by variations in rainfall in the Indian Ocean during the monsoon has been reported [36,83]. It has been demonstrated that sea surface temperature in the Bay of Bengal is correlated with algal blooms and outbreaks of cholera in Bangladesh. V. cholerae occur in the Gulf of México and along the east coast of North America, where most blooms occur during the summer months and relatively high water temperatures are necessary for algal growth and bloom formation that are directly or indirectly hazardous to human health $[76,84]$. Climate variability and change may thus influence the introduction of cholera into coastal populations [15]. According to Huq et al. (2005) [58], environmental sampling and analysis of the environmental and clinical data revealed significant correlations of water temperature, water depth, rainfall, conductivity, and copepod counts with the occurrence of cholera toxin producing bacteria (presumably $V$. cholerae). The lag periods between increases or decreases in units of factors, such as temperature and salinity, and occurrence of cholera correlate with biological parameters, e.g., plankton population blooms. The new information on the ecology of $V$. cholerae is proving useful in developing environmental models for the prediction of cholera epidemics.

Recently, one factor involved in adherence of $V$. cholerae $\mathrm{O} 1$ to the chitin of zooplankton, and then in addition acquiring acid tolerance, was identified as the mannose-sensitive hemagglutinin (MSHA) type IV pili. V. cholerae O1 El Tor and O139 strains expressed and assembled these pili; nevertheless, 01 classical strains carry the pili (msh) genes but do not assemble functional MSHA pili [85-87]. V. cholerae also possess secreted chitinase enzyme(s) which are probably needed to utilize chitin (homopolymer of $\mathrm{N}$ acetylglucosamine) as a carbon source [88]; the hypothetical chi gene products were identified in the genome sequence [89]. These findings are suggestive of a close association of $V$. cholerae with chitin structures in the environment (e.g. zooplankton such as copepods) [90]. V. cholerae respond efficiently to different and constantly changing ecosystems due to a variety of transport proteins with broad substrate specificity and catabolic pathways located on its chromosomes. For example, ribose and lactate transport and degradation enzymes are contained on chromosome 2, whereas the trehalose systems reside on chromosome 1; nevertheless, other energy metabolism pathways like the chitin system are split between the chromosomes [89]. In aquatic environments, chitin represents a source of both carbon and nitrogen. Sequence analysis suggests that Vibrio cholerae degrades chitin by a phosphenolpyruvate phosphotransferase system (PTS) for chitobiose transport [91].

Several studies have demonstrated that environmental non-O1 and non-O139 V. cholerae strains and $V$. cholerae $\mathrm{O} 1 \mathrm{EI}$ Tor and $\mathrm{O} 139$ are able to form a three-dimensional biofilm on surfaces which provides a microenvironment [9293], increasing bacterial productivity that favors survival and persistence due to increased resistance to various harmful environmental conditions, including chlorination and antibiotics [94-95]. Biofilm formation is likely to be important for the life cycle of $V$. cholerae, facilitating environmental persistence within natural aquatic habitats during interepidemic periods [90]. For both V. cholerae $\mathrm{O} 1 \mathrm{El}$ Tor and 0139 strains, biofilm formation is dependent on the expression of an exopolysaccharide (EPS) [93,96]. Expression of the Vibrio polysaccharide synthesis genes (vps), encoded in two gene clusters on the larger chromosome ( $v p s A-K$ and $v p s L-Q$ ), is required for synthesis of an EPS matrix that stabilizes the mature biofilm. Overproduction of EPS results in resistance to osmotic and oxidative stress and bacteriocidal agents [97]. Strains containing defects in one of the vps genes necessary for exopolysaccharide synthesis fail to make a threedimensional biofilm, indicating that the exopolysaccharide is used to build a mature biofilm [93]. Expression of the vps exopolysaccharide causes a rugose colony phenotype, and provides enhanced chlorine and phage resistance [98-99]. The expression of vps inhibited intestinal colonization in an infant mouse cholera model, suggesting that the expression of a factor that enhances environmental persistence actually decreases virulence [93]. The lack of flagellar synthesis causes high-level vps exopolysaccharide expression (at least in some 
strains, e.g. 0139), indicating that flagellar synthesis is coupled to vps expression. This effect is specifically due to the lack of a flagellum, rather than a lack of motility, suggesting that the loss of the flagellum may be a developmental cue during biofilm formation [93].

Kierek and Watnick (2003) [100] identified and characterized a vps-dependent $V$. cholerae biofilm and a vps-independent $V$. cholerae biofilm. The vps-dependent biofilm predominated in growth media containing monosaccharides. They hypothesized that vps-dependent biofilm development occurs only in nutrient-rich environments. Transcription of $v p s$ is greater in biofilm-associated cells than in planktonic cells, suggesting that vps gene transcription is activated by surface association [101]. This type of biofilm development may facilitate $V$. cholerae's colonization of favorable aquatic environments. Conversion of environmental monosaccharides into an exopolysaccharide matrix may even serve as a form of nutrient storage. In contrast, millimolar $\mathrm{Ca}^{2+}$ concentrations, which are present in seawater but not in freshwater, are required for vps-independent biofilm development. Thus, Kierek and Watnick hypothesized that vpsindependent biofilm development probably occurs primarily in marine environments. In contrast to the variability of organic nutrients in aquatic environments, the concentration of $\mathrm{Ca}^{2+}$ is uniformly high in the marine environment. Thus, $V$. cholerae surface adhesion in marine environments may be less discriminating. As cholera epidemics have been associated with heavy rainfall and increases in sea surface height [10, 29], both of these conditions are predicted to alter the organic and inorganic compositions of an estuary, which is the primary interface between humans and the marine environment [102-105]. These changes in the organic and inorganic compositions of the aquatic environment may alter the nature of $V$. cholerae's association with surfaces and may play some role in the initiation of cholera epidemics.

Evidence indicates that $V$. cholerae toxigenic strains may arise from environmental, nontoxigenic progenitors in coastal areas, as nutrientrich effluents and warmer sea surface temperatures shift marine ecosystems towards more toxic species $[10,19,63]$. Most $V$. cholerae strains, especially those from the environment, lack the genes required to produce $\mathrm{CT}$, but the possibility of genetic exchange in the environment by horizontal transfer of phage transduction with cholera toxin (CT)-encoding phage CTX- $\Phi$ mechanism as well as clonal diversity allows the potential emergence of new toxigenic clones [106107]. Expression of CT is optimal at salinities between 2 and 2.5 psu. Castañeda et al. (2005) [59] reported that conditions found in Alvarado and La Mancha lagoons (Veracruz, México) might favor $V$. cholera O1 enterotoxin positive occurrence during the rainy season. Evidence for serconversion, in part, may explain this observation. Only serogroup $\mathrm{O} 1$ and the newly emerged 0139 have been associated with severe disease and cholera pandemics. In contrast, intestinal and/or extraintestinal infections with non$\mathrm{O} 1$ and -0139 serogroups or non-toxigenic $\mathrm{O} 1$ strains are rarely found and seem to be of little clinical significance. The majority of environmental isolates of $V$. cholerae are members of non-O1 and non-O139 serogroups and lack the genes required to produce cholera toxin (CT) [108].

\section{Temporal and spatial variability}

The deteriorating conditions of the environment and climate change have led to concerns in the influence of climate on disease dynamics. Seasonality in disease incidence might infer an association with weather factors. It has been attributed to seasonal changes in pathogen transmission rates, resulting from fluctuations in extrinsic climate factors. Climate modulates the seasonal and inter-seasonal variability of cholera by affecting both the prevalence and the spatial distribution of the agent in the environment through numerous mechanisms that affect the seasonality of cholera incidence unique for each geographical location. In addition to seasonal variability, endemic areas experience inter-seasonal increases in cholera incidences that have been closely linked to climate variability [109].

The confirmation that $V$. cholerae occurs in aquatic environments in association with zooplankton and phytoplankton, and the associations found between cholera cases and sea surface temperature and sea surface heights indicates that cholera dynamics are strongly associated with climate and seasonal variability $[36,41-42,64,67,110]$. The increase in sea surface heights (SSH) might cause inland incursion of contaminated water containing zooplankton, and 
human contact with $V$. cholerae. SSH is modulated by seasonal thermal expansion and contraction of sea water, ocean currents, tidal forces, and the piling up of water resulting from persistent winds and other atmospheric phenomenon [10]. The complex interactions and feedbacks between the dynamics and the ecology of endemic areas result in favorable conditions for the propagation and transmission of the bacteria.

Based on quantitative empirical studies, relationships have been shown to exist between cholera epidemics, land and sea surface temperature anomalies (LSTAs), rainfall, and ENSO, with the latter parameter quantified by the Southern Oscillation Index (SOI) for the Asian and South American subcontinents [11,41,57,67,111114]. In particular, an increased role of interannual climate variability in cholera interannual dynamics in Bangladesh has been suggested, with strong and consistent signature of ENSO, at least for certain time periods [57]. In an epidemiological endemic context, these findings suggest that certain aspects of climate are associated with human cholera incidence in specific areas of the intertropical belt [7].

The Rodó et al. (2002) [57] study represents the first evidence that warming trends are affecting human disease. Using an extensive cholera database and innovative statistical methods they found quantitative evidence for an increased role of interannual climate variability on the temporal dynamics of cholera. They provided evidence for an increase over time in the frequency and amplitude in the ENSO. According to their findings, there is a robust association of cholera dynamics and ENSO, from the first to the last decades of the 20th century, based on time-series analyses of the relationship between ENSO and cholera prevalence in Bangladesh (formerly Bengal) during two different time periods. Even though debate still remains regarding the relationship between ENSO intensification and climate change, the observations of Rodó et al. are consistent with warming models. A strong and consistent signature of ENSO is apparent in the last two decades (1980-2001), while it is weaker and eventually uncorrelated during the first parts of the last century (1893-1920 and 1920-1940, respectively), and the SOI undergoes shifts in its frequency spectrum as well. Their results indicated that a change in remote ENSO modulation alone can only partially serve to substantiate the differences observed in cholera. Regional or basinwide changes possibly linked to climate changes, mainly warming, seem to facilitate ENSO transmission, as this climate phenomenon accounts for over $70 \%$ of disease variance.

Koelle et al. (2005b) [114] have demonstrated the linkages across time and space scales in the dynamics of the regional system (climate patterns, river basin rainfall variability, river discharge, and flooding), $V$. cholerae, and non-linear human susceptibility levels. According to their study, water temperature in ponds and rivers provides another local mechanism for the remote association of cholera transmission with SST in the Bay of Bengal and the Pacific ENSO, and other factors such as changes in cloud cover, wind stress and evaporation modulate variations in the net heat flux entering the system increasing both the SST in the Bay of Bengal and affecting the surface temperature over land. The resulting warming of water temperature in ponds and rivers might increase the incidence of cholera through the faster growth rate of the pathogen in aquatic environments. The results of Koelle et al. showed a critical interplay of environmental forcing, specifically climate variability, and temporary immunity explained by the interannual disease cycles presented in four-decade cholera time series from Matlab, Bangladesh. By reconstructing the transmission rate, affected by extrinsic forcing over time for the predominant strain (El Tor), a non-linear population model permitted a contributing effect of intrinsic immunity. According to their findings, transmission showed clear interannual variability with a strong correspondence to climate patterns at long periods (over 7 years, for monsoon rains and Brahmaputra river discharge) and at shorter periods (under 7 years, for flood extent in Bangladesh, sea surface temperatures in the Bay of Bengal and the El Niño-Southern Oscillation).

The study by De Magny et al. (2006) [110] was the first to document the existence of an association between climate and cholera outbreaks on the African continent, using the wavelet method to explore periodicity in (i) a longtime monthly cholera incidence in Ghana, West Africa, (ii) proxy environmental variables, and (iii) climatic indices time series, from 1975 to 1995. Cross-analysis was done to explore links between 
cholera and climate. Results showed strong statistical association from the end of the 1980s, between cholera outbreak resurgences in Ghana and the climatic/environmental parameters. Results of coherence revealed the existence of strong associations between (i) cholera case incidence and rainfall, and (ii) disease incidence and LSTA1 (Land Surface Temperature Anomaly) time series. The influence of warm events may have an impact on the bacterial populations and that of their host reservoirs, providing new favorable environmental conditions such as an increase in temperature in shallow bodies of water, i.e., lagoons, estuaries, and coastal waters.

\section{Future Considerations}

Different scenarios predict health adverse consequences in different regions of the world in the coming decades due to climate change [115117]. Associated land use and transformation of resource production (urbanization, agricultural expansion and intensification, and natural habitat alteration) have produced changes in ecological systems, notably in landscapes and, in turn, their natural communities and ultimately in their pathogen, animal host, and human populations. Factors related to public health infrastructure and climate variability, and their interactions with regional environmental change also may contribute significantly to disease emergence [28].

In addition to natural climate variability and climate shifts, the climate change contribution may well contribute further to disease emergence [118]. Environmental/ecological changes and economic inequities strongly influence disease patterns. Nevertheless, an ever-increasing role of a warming and unstable climate is driving the global emergence, resurgence and redistribution of infectious diseases [27]. Regional environmental change, which is influenced significantly by population growth, resource consumption, and waste generation, plays an important role in the emergence of infectious disease, especially in tropical developing regions. Tropical climate, poor water and food security, low socio-economic status and political instability define the regions that would be most vulnerable to the health effects of climate change [13,119]. Many Latin American countries have these conditions in common. Therefore, there is a need in Latin America to identify areas where populations are vulnerable to the health impacts of climate change, since populations with the fewest resources would be the most vulnerable to the adverse health effects of climate change. Epidemiological surveillance of areas under risk would provide better knowledge of how climate change may impact human health. There are areas where diseases are likely to respond to a change in climate and where the population at risk is large with limited capacity to respond to emerging disease threats [120].

Humans have the potential to affect $V$. cholerae abundance and transmission at multiple spatial scales. Human activities at a local scale such as land-use change, pollution (including sewage), aquaculture and fisheries management, have the potential to alter water temperature and nutrient concentrations, which may directly affect conditions for growth, or indirectly, the distribution, abundance, and composition of the plankton. On a broader spatial scale, human-induced climate change could alter $V$. cholerae dynamics by changing the microbe's seasonal regimes or facilitating its spread to new areas [121]. From an applied perspective, clarifying the mechanisms that link seasonal environmental changes to diseases' dynamics will aid in forecasting longterm health risks and in developing strategies for controlling diseases across a range of human and natural systems. This is especially important because longer-term environmental changes caused by climate warming and complex events like ENSO will alter seasonality in ways that influence the spread of disease [19,41].

Research on the links between climate and infectious diseases must be strengthened in order to examine the consistency of climate/disease relationships in different social contexts and across a variety of temporal and spatial scales. Clarifying the causal pathways linking climate to disease prevalence will require additional knowledge of the ecology of the pathogen and the transmission dynamics of infectious disease. A clearer understanding of the current role of climate change in disease patterns will enable scientists to improve forecasts of future potential impacts [120]. The sooner these consequences are estimated and communicated the better will be the chance of averting future retrograde policy decisions [122].

The persistence of $V$. cholerae as part of the normal flora in aquatic environments, the lack of an effective vaccine, and increasing antibiotic 
resistance among strains isolated from cholera patients all suggest that cholera will not be eradicated in the future. As with other tropical diseases, there is growing concern that the combination of climate change, anthropogenic disturbance of local environments, and transport due to travel and trade will expand the range of endemic strains, and consequently create more focal points for cholera outbreaks. As socioeconomic conditions favorable to cholera persist in many countries, revealing the influence of climatic/environmental factors in seasonal patterns is critical to understanding temporal variability of cholera at longer time scales, including trends and interannual variability to improve disease forecasting. An understanding of disease risk related to the environment can also call attention to the need for improving these conditions. A more complete understanding of the ecology of $V$. cholerae is critical to identify and comprehend the seasonality and regional mechanisms as a function of environmental factors for the prediction and management of this disease.

\section{References}

1. Walther GR, Post E, Convey P, Menzel A, Parmesank C, Beebee TJC, Fromentin J-M, Guldberg OH and Bairlein F (2002) Ecological responses to recent climate change. Nature 416:389-395.

2. Anthes RA, Moore B, Anderson JG, Barron BEJ, Brown OB Jr, Cutter SL, De Fries R, Gaiel WB, Hager BH, Hollingsworth A, Janetos AC, Kelly KA, Lane NF, Lettenmaier DP, Traw B M, Mika AM, Washington WM, Wilson ML, Zoback ML (2007) Earth Science and Applications from Space: National Imperatives for the Next Decade and Beyond. National Research Council of the National Academies, Space Studies Board, Division on Engineering and Physical Sciences. Washington DC, USA: The National Academies Press.

3. Rees R (1996) Under the weather: climate and disease, 1700-1900. History Today 46:35-42.

4. World Health Organization (2002) The World Health Report 2002. Geneva: WHO.

5. McMichael A (2004) Environmental and social influences on emerging infectious diseases: past, present and future. Phil Trans R Soc Lond B 359: 1049-1058.

6. Huq A and Colwell RR (1996) Environmental factors associated with emergence of disease with special reference to cholera. Eastern Medit HIth J 2:37-45.

7. World Health Organization (2005) Available: http://www.who.int

8. Bonilla-Castro E, Rodríguez P, Carrasquilla G (2000) La Enfermedad de la Pobreza, El Cólera en los Tiempos Modernos. Santafé de Bogotá: Ediciones Uniandes.

9. Colwell RR and Patz JA (1998) Climate, infectious disease and health: an interdisciplinary perspective. Washington DC: American Academy of Microbiology.
10. Lobitz B, Beck L, Huq A, Wood B, Fuchs G, Faruque ASG, and Colwell RR (2000) Climate and infectious disease: use of remote sensing for detection of Vibrio cholerae by indirect measurement. Proc. Natl Acad Sci USA 97:1438-1443.

11. Pascual M, Rodo X, Ellner SP, Colwell RR, and Bruma MJ (2000) Cholera dynamics and El Niño-southern oscillation. Science 289:1766-1769.

12. Epstein PR (2001) Climate change and emerging infectious diseases. Microbes and Infection 3: 747-754.

13. Moreno AR (2006) Climate change and human health in Latin America: drivers, effects, and policies. Reg Environ Change 6: 157-164.

14. Chan NY, Ebi K, Smith F, Wilson TF and Smith AE (1999) An integrated assessment framework for climate change and infectious diseases. Environmental Health Perspectives 107: 329-337.

15. Haines A, McMichael AJ, Epstein PR (2000) Environment and health: 2. Global climate change and health. Can Med Assoc J 163:729-734.

16. Rivera Tapia JA (2003) Environment and Health. Anales Médicos Hospital ABC 48:223-227.

17. Ebi KL (2007) Healthy people 2100: modeling population health impacts of climate change. Climatic Change. Springer-Verlag.

18. Rose JB, Epstein PR, Lipp EK, Sherman BH, Bernard SM, and Patz JA (2001) Climate variability and change in the United States: potential impacts on water- and foodborne diseases caused by microbiological agents. Environ Helth Perspect 109 (suppl.2):211-222.

19. Harvell CD, Mitchell CE, Ward JR, Altizer S, Dobson AP, Ostfeld RS, Samuel M D (2002) Climate warming and disease risk for terrestrial and marine biota. Science 296:2158-2162.

20. Prüss A and Havelaar A (2001) The global burden of disease study and applications in water, sanitation and hygiene. In Fewtrell $\mathrm{L}$ and Bartram $\mathrm{J}$ editors. Water Quality: Guidelines, Standards and Health. London: IWA Publishing. 43-59.

21. Gleick PH (2002) Dirty Water: Estimated deaths from water-related diseases 2000-2020. Pacific Institute for Studies in Development, Environment, and Security • www.pacinst.org.

22. Charron DF, Thomas MK, Waltner-Toews D, Aramini JJ, Edge T, Kent RA, Maarouf AR, Wilson J (2004) Vulnerability of waterborne diseases to climate change in Canada: A review. J Toxicol Environm Health, Part A, 67:1667-1677.

23. Curriero FC, Patz JA, Rose JB, and Lele S (2001) The association between extreme precipitation and waterborne disease outbreaks in the United States, 1948-1994. Am J Public Health 91:1194-1199.

24. Hunter PR (2003) Climate change and waterborne and vector-borne disease. J Appl Microbiol 94:37S-46S.

25. Hayes M, Bonaventura J, Mitchell TP, Prospero JM, Shinn EA, Van Dolah F and Barber RT (2001) How are climate and marine biological outbreaks functionally linked?. Hydrobiologia 460: 213-220.

26. Heidelberg JF, Heidelberg KB, Colwell RR (2002) Seasonality of Chesapeake Bay bacterioplankton species. Appl Environm Microbiol 68:5488-5497. 
27. McMichael A, Woodruff RE, Hales S (2006) Climate change and human health: present and future risks. Lancet 367:859-869.

28. Burke D, Carmichael A, Focks D, Gimes D, Harte J, Lele S, Martens P, Mayer J, Mearns L, Pulwarty R, Leal L, Ropelewski Ch, Rose J, Shope R, Simpson J, Wilson M (2001) Under the Weather: Climate, Ecosystems, and Infectious Disease. Committee on Climate, Ecosystems, Infectious Diseases, and Human Health, Board on Atmospheric Sciences and Climate, National Research Council, Division on Earth and Life Studies, National Research Council. National Academy of Sciences. Washington DC, U.S.A.: The National Academy Press.

29. Lipp EK, Huq A, Colwell RR (2002) Effects of global climate on infectious disease: The cholera model. Clin Microbiol Rev 15: 757-770.

30. Villalpando S, Eusebio MG, Aviles D (2000) Detection of Vibrio cholerae $\mathrm{O} 1$ in oysters by the visual colorimetric immunoassay and the cultura technique. Rev Latinoamer Microbiol 42:63-68.

31. World Health Organization (2005) Cholera, 2004. Weekly Epidemiological Record 80:261-268

32. Smith KF, Dobson AP, McKenzie FE, Real LA, Smith DL, Wilson ML (2005) Ecological theory to enhance infectious disease control and public health policy. Frontiers in Ecology and the Environment 3:29-37.

33. UNEP (2005) Emerging challenges-new findings. In Geo Year Book 2004-2005: an Overview of Our Changing Environment. New York: United Nations Publications. 71-79.

34. Seas C, Miranda J, Gil Al, Leon-Baru R, Patz JA, Huq A, Colwell RR and Sack R B (2000) New insights on the emergence of cholera in Latin America during 1991. The Peruvian experience. Am J Trop Med Hyg 62:513-517.

35. Borroto RJ and Martínez-Piedra R (2000) Geographical patterns of cholera in Mexico, 1991-1996. Int J Epidemiol 29:764-772.

36. Colwell RR (1996) Global climate and infectious disease: the cholera paradigm. Science 274:2025-2031.

37. Whittman RJ, Flick GJ (1996) Microbial contamination of shellfish prevalence risk to human health and control strategies. Annual Rev Public Hlth 16:123-140.

38. Daniels NA, MacKinnon L, Bishop R, Altekruse S, Bay B, Hammond RM, Thompson S, Wilson S, Bean NH, Griffin PM, Slutsker L (2002) Vibrio parahaemolyticus infections in the United States, 1973-1998. J Infect Dis 181:16611666.

39. Potasman I, Paz A, Odeh M 2002. Infectious otbreaks associated with bivalve shellfish consumption: a worldwide perspective. Clin Infect Dis 35:921-928.

40. Scott Gl, Fulton MH, Wirth EF, Chandler GT, Key PB, Daugomah JW, Bearden D, Chung KW, Strozier ED, DeLorenzo M, Siversten S, Dias A, Sanders M, Macauley JM, Goodman LR, LaCroix MW, Thayer GW, Kucklick J (2002) Toxicological studies in tropical ecosystems: an ecotoxicological risk assessment of pesticide runoff in south Florida estuarine ecosystems. J Agric Food Chem 50:4400-4408.

41. Pascual M, Bouma MJ, Dobson AP 2002. Cholera and climate: revisiting the quantitative evidence. Microbes and Infection 4:237-245.
42. Koelle K, Pascual M, Yunus M (2005) Pathogen adaptation to seasonal forcing, climate change. Proc Royal Soc London B 272:971-977.

43. Singleton FL, Attwell R, Jangi S, Colwell RR (1982) Effects of temperature and salinity on Vibrio cholerae growth. App Environm Microbiol 44:1047-1058.

44. Barbieri E, Falzano L, Fiorentini C, Pianitti A, Baffone W, Fabbri A, Matarrese P, Caisere A, Katouli M, Kühn I, Mölby F, Bruscolini F, Donelli G (1999) Occurrence, diversity, and pathogenicity of halophilic Vibrio spp. and Non $\mathrm{O} 1$ Vibrio cholerae from estuarine waters along the Italian Adriatic Coast. Appl Environm Microbiol 65: 27482753.

45. Jiang SC (2001) Vibrio cholerae in recreational beach waters and tributaries of Southern California. Hydrobiologia 460:157-164.

46. McDougald D, Rice SA, Weichart D, and Kjelleberg S (1998) Nonculturability: adaptation or debilitation? FEMS Microbiol Ecol 25: 1-9.

47. Xu HS, Roberts NC, Singleton FL, Attwell RW, Grimes DJ, and Colwell RR (1982) Survival and viability of nonculturable Escherichia coli and Vibrio cholerae in the estuarine and marine environment. Microb Ecol 8:313323

48. Huq A, Rivera ING and Colwell RR (2000) Epidemiological significance of viable but nonculturable microorganisms. In Colwell RR and Grimes DJ editors. Nonculturable microorganisms in the environment. Washington DC: American Society of Microbiology Press.

49. Franco AA, Fix D, Prada A, Paredes E, Palomino C, Wright $\mathrm{C}$, Johnson JA, McCarter R, Guerra $\mathrm{H}$ and Morries JE (1997) Cholera in Lima, Peru correlates with prior isolation of Vibrio cholerae from the environment. Am J Epidemiol 146(12):1067-1075.

50. Barnett TP, Pierce DW and Schnur R (2001) Detection of antropogenic climate change in the world's oceans. Science 292:270-274.

51. International Panel on Climate Change (IPCC) (2001) Climate change 2001: Impacts, Adaptation and Vulnerability. The scientific basis. Contribution of Working Group I to the third assessment report of the Intergovernmental Panel on Climate Change. Canziani $O$ and McCarthy $\mathrm{J}$ editors. Cambridge, UK: Cambridge Univ. Press.

52. International Panel on Climate Change (IPCC) (2001) Climate change 2001: The scientific basis. In Houghton JT, Ding Y, Griggs DJ, Noguer M, van der Linden P J, Dai $\mathrm{X}$, Maskell $\mathrm{K}$, Johnson CA editors. Contribution of Working Group I to the third assessment report of the Intergovernmental Panel on Climate Change. Cambridge, UK: Cambridge University Press. 881.

53. International Panel on Climate Change (IPCC) (2001) Climate change 2001: Impacts, Adaptation and Vulnerability. In McCarthy JJ, Canziani OF, Leary NA Dokken DJ, White KS editors. Contribution of Working Group II to the third assessment report of the Intergovernmental Panel on Climate Change. Cambridge, UK: Cambridge University Press. 1032.

54. Patz JA, Campbell-Lendrum D, Holloway T, Foley JA (2005) Impact of regional climate change on human health. Nature 7066:310-317.

55. Patz JA, McGeehin MA, Bernard SM, Ebi KL, Epstein PR, Grambsch A, Gubler D J, Reiter P, Romieu I, Rose JB 
Samet JM and Trtanj J (2000) The potential health impacts of climate variability and change for the United States: Executive summary of the report of the health sector of the U.S. national assessment. Env Hlth Perspec 108:367-376.

56. Louis VR, Cohen E, Choopun N, Rivera I, Gangle B, Jiang S, Rubin A, Patz J, Huq A, Colwell RR (2003) Predictability of Vibrio cholerae in Chesapeake Bay. Appl Environm Microbiol 69:2773-2785.

57. Rodó X, Pascual M, Fuchs G, Faruque ASG (2002) ENSO and cholera: A nonstationary link related to climate change. Proc Natl Acad Sci USA 99:12901-12906.

58. Huq A, Sack RB, Nizam A, Longini IM, Nair GB, Ali A, Morris JG Jr, Khan MN, Siddique AK, Yunus M, Albert MJ, Sack DA and Colwell RR (2005) Critical Factors Influencing the Occurrence of Vibrio cholerae in the Environment of Bangladesh. Appl Environ Microbiol 71:4645-4654.

59. Castañeda Chávez MR, Pardío V, Orrantia E, Lango F (2005) Influence of water temperature and salinity on seasonal occurrences of Vibrio cholerae and enteric bacteria in oyster-producing areas of Veracruz, México. Mar Poll Bull 50:1641-1648.

60. Mahasneh AM and Al-Sayed HA (1997) Seasonal incidence of some heterotrophic aerobic bacteria in Bahrain pelagic and nearshore waters and oysters. Intern J Environ Studies 51:301-12.

61. Munro PM and Colwell RR (1996) Fate of Vibrio cholerae O1 in seawater microcosms. Water Res 1:47-50.

62. Singleton FL, Attwell R, Jangi S, Colwell RR (1982) Influence of salinity and organic nutrient concentration on survival and growth of Vibrio cholerae in aquatic microcosms. Appl Environm Microbiol 43:1080-1085.

63. Epstein PR (1993) Algal blooms in the spread and persistence of cholera. BioSystems 31:209-221.

64. Colwell RR, Huq A (2001) Marine ecosystems and cholera. Hydrobiologia 60:141-145.

65. Islam MS, Drasar BS, Bradley DJ (1990) Long-term persistence of toxigenic Vibrio cholerae $\mathrm{O} 1$ in the mucilaginous sheath of a blue-green alga, Anabaena variabilis. J Trop Med Hyg 93:133-139.

66. Montilla R, Chowdhury MA, Huq A, Xu B, Colwell RR (1996) Serogroup conversion of Vibrio cholerae non-O1 to Vibrio cholerae 01: effect of growth state of cells, temperature, and salinity. Can J Microbiol 42:87-93

67. Bouma MJ, Pascual M (2001) Seasonal and interannual cycles of endemic cholera in Bengal 1891-1940 in relation to climate and geography. Hydrobiologia 460:147-156.

68. Piarroux R, Bompangue D (2006) Needs for an integrative approach of epidemics: the example of cholera. In Tibayrenc M editor. Encyclopedia of Infectious Diseases: Modern Methodologies. Chichester, UK: John Wiley \& Sons Ltd.

69. Huq A, Small EB, West PA, Huq MI, Rahman $R$ and Colwell RR (1983) Ecological relationships between Vibrio cholerae and planktonic copepods. Appl Environ Microbiol 45:275-283.

70. Huq A, Colwell RR, Rahmann R, Ali A, Chowdhury MAR, Parveen S, Sack DA and Russek-Chohen R (1990) Detection of Vibrio cholerae $\mathrm{O} 1$ in the aquatic environment by fuorescent-monoclonal antibody and culture methods. Appl Environ Microbiol 56: 2370-2373.
71. Tamplin ML (2001) Coastal Vibrios: identifying relationships between environmental condition and human disease. Human and Ecological Risk Assessment 7(5): $1437-1445$

72. Huq A, West PA, Small EB, Huq MI, and Colwell RR (1984) Influence of water temperature, salinity, and $\mathrm{pH}$ on survival and growth of toxigenic Vibrio cholerae serovar O1 associated with live copepods in laboratory microcosms. Appl Environ Microb 48: 420-24.

73. Islam MS, Drasar BS, Sack RB (1994) The aquatic flora and fauna as reservoirs of Vibrio cholerae: a review. J Diarrh Dis Res 12:87-96.

74. Islam MS, Rahim Z, Alam MJ, Begum S, Moniruzzaman SM, Umeda A, Amakao K, Albert MJ, Sack RB and Colwell RR (1994) Detection of non-culturable Vibrio cholerae $\mathrm{O} 1$ associated with a cyanobacterium from the aquatic environment in Bangladesh. Trans $\mathrm{R}$ Soc Trop Med Hyg 88:198-199.

75. Islam MS, Rahim Z, Alam MJ, Begum S, Moniruzzaman SM, Umeda A, Amakao K, Albert MJ, Sack RB and Colwell RR (1999) Association of Vibrio cholerae O1 with the cyanobacterium, Anabaena sp., elucidated by polymerase chain reaction and transmission electron microscopy. Trans R Soc Trop Med Hyg 93:36-40.

76. Jacoby JM, Collier DC, Welch EB, Hardy FJ and Crayton M (2000) Environmental factors associated with a toxic bloom of Microcystis aeruginosa. Can J Fish Aquat Sci 57: 231-240.

77. Wright AC, Hill RT, Johnson JA, Roghman MC, Colwell RR, Morris JG Jr (1996) Distribution of Vibrio vulnificus in the Chesapeake Bay. Appl Environ Microbiol 162:71724.

78. Morris JG Jr (2003) Cholera and other types of vibriosis: A story of human pandemics and oysters on the half shell. Clin Infect Dis 37:272-280.

79. Colwell RR and Grimes DJ (2000) Nonculturable Microorganisms in the Environment. Washington DC: ASM Press.

80. Mezrioui N, Oufdou K and Baleux B (1995) Dynamics of non-O1 Vibrio cholerae and fecal coliforms in experimental stabilization ponds in the arid region of Marrakesh, Morocco, and the effect of sunlight on their experimental survival. Canadian J Microbiol 41:489-498.

81. Epstein PR, Ford TE, Colwell RR (1993) Health and climate change: Marine ecosystems. Lancet 342:12161219.

82. Colwell RR, Huq A, Islam MS, Aziz KMA, Yunus M, Khan $\mathrm{NH}$, Mahmud A, Sack RB, Nair GB, Chakraborty J, Sack DA, Russek-Cohen E (2003) Reduction of cholera in Bangladehi villages by simple filtration. Proc Natl Acad Sci USA 100:1051-1055

83. Faruque SM, Naser IB, Islam MJ, Faruque AS, Ghosh AN, Nair GB, Sack DA and Mekalanos JJ (2005) Seasonal epidemics of cholera inversely correlate with the prevalence of environmental cholera phages. Proc Natl Acad Sci USA 102:1702-1707

84. Saker ML and Griffiths DJ (2001) Occurrence of blooms of the cyanobacterium Cylindrospermopsis raciborskii (Woloszynska) Seenayya and Subba Raju in a north Queensland domestic water supply. Marine and Freshwater Research 52: 905-915. 
85. Watnick PI and Kolter R (1999) Steps in the development of a Vibrio cholerae El Tor biofilm. Mol Microbiol 34: 586595.

86. Chiavelli DA, Marsh JW and Taylor RK (2001) The mannosesensitive hemagglutinin of Vibrio cholerae promotes adherence to zooplankton. Appl Environ Microbiol 67:3220-3225.

87. Reguera $G$ and Kolter R (2005) Virulence and the environment: a novel role for Vibrio cholerae toxincoregulated pili in biofilm formation on chitin. J. Bacteriol. 187:3551-3555.

88. Connell T. D., Metzger D. J., Lynch J. and Folster J. P. 1998. Endochitinase is transported to the extracellular milieu by the eps-encoded general secretory pathway of Vibrio cholerae. J. Bacteriol. 180;5591-5600.

89. Heidelberg JF, Elsen JA, Nelson WC, Clayton RJ, Gwinn ML, Dodson RJ, Haft D H, Hickey EK, Peterson JD, Umayam L, Gill SR, Nelson KE, Read TD, Gill SR, Nelson KE, Read TD, Tettlin H, Richardson D, Ermolaeva MD, Vamathevan J, Bass S, Qin H, Dragoi I, Sellers P, Mcdonald L, Utterback T, Fleishmann RD, Nierman WC, White O, Salzberg SL, Smith HO, Colwell RR, Mekalanos JJ, Craig J and Frase CM (2000) DNA sequence of both chromosomes of the cholera pathogen. Nature 406: 477484.

90. Reidl J and Klose KE (2002) Vibrio cholerae and cholera: out of the water and into the host. FEMS Microbiol Rev 26:125-39.

91. Bassler BL, Yu C, Lee YC and Roseman S (1991) Chitin utilization by marine bacteria. Degradation and catabolism of chitin oligosaccharides by Vibrio furnissii. $\mathrm{J}$ Biol Chem 266: 24276-4286.

92. Broza $M$ and Halpern $M$ (2001) Pathogen reservoirs: Chironomid egg masses and Vibrio cholerae. Nature 412:40.

93. Watnick PI, Lauriano CM, Klose KE, Croal $L$ and Kolter $R$ (2001) The absence of a flagellum leads to altered colony morphology, biofilm development and virulence in Vibrio cholerae 0139. Molec Microbiol 39(2):223-235.

94. Davey ME and O'Toole GA (2000) Microbial biofilms: from ecology to molecular genetics. Microbiol Mol Biol Rev 64: 847-67.

95. O'Toole G, Kaplan HB, and Kolter R (2000) Biofilm formation as microbial development. Annu Rev Microbiol 54: 49-79.

96. Wai SN, Mizunoe Y, Takade A, Kawabata S-I and Yoshida S-I (1998) Vibrio cholerae O1 strain TSI-4 produces the exopolysaccharide materials that determine colony morphology, stress resistance, and biofilm formation. Appl Environ Microbiol 64:3648-3655.

97. Yildiz FH and Schoolnik GK (1999) Vibrio cholerae $01 \mathrm{El}$ Tor: identification of a gene cluster required for the rugose colony type, exopolysaccharide production, chlorine resistance, and biofilm formation. Proc Natl Acad Sci USA 96: 4028-4033.

98. Morris JG, Sztein MB, Rice EW, Nataro JP, Losonsky GA, Panigrahi P, Tacket C O and Johnson JA (1996) Vibrio cholerae $\mathrm{O} 1$ can assume a chlorine-resistant rugose survival form that is virulent for humans. J Infect Dis 174:1364-1368.

99. Nesper J, Lauriano CM, Klose KE, Kapfhammer D, Kraib A and Reidl JA (2001) Characterization of Vibrio cholerae O1 El Tor galU and galE Mutants: Influence on
Lipopolysaccharide Structure, Colonization, and Biofilm Formation. Infection and Immunity 69:435-445.

100.Kierek K and Watnick PI (2003) Environmental determinants of Vibrio cholerae biofilm development. App Environm Microbiol 69(9):5079-5088.

101. Haugo AJ and Watnick PI (2002) Vibrio cholerae CytR is a repressor of biofilm development. Mol Microbiol 45:471-483.

102. Reemtsma T, Ittekkot V, Bartsch M, and Nair RR (1993) River inputs and organic-matter fluxes in the northern Bay of Bengal. Chem Geol 103:55-71.

103. Mahadevan A and Subramanian B (1999) Seasonal and diurnal variation of hydrobiological characters of coastal water of Chennai (Madras), Bay of Bengal. Indian J Mar Sci 28:429-433.

104.Padmavathi D and Satyanarayana D (1999) Distribution of nutrients and major elements in riverine, estuarine and adjoining coastal waters of Godavari, Bay of Bengal. Indian J Mar Sci 28:345-354.

105. Han WQ and Webster PJ (2002) Forcing mechanisms of sea level interannual variability in the Bay of Bengal. J Phys Oceanogr 32:216-239.

106. Faruque SM, Albert MJ and Mekalanos JJ (1998) Epidemiology, genetics, and ecology of toxigenic Vibrio cholerae. Microbiol Mol Biol Rev 62: 1301-1314.

107. Chakraborty S, Mukhopadhyay AK, Bhadra RK, Ghosh AN, Mitra R, Shimada T, Yamasaki S, Faruque SM, Takeda Y, Colwell RR and Mair GB (2000) Virulence genes in environmental strains of Vibrio cholerae. Appl Environ Microbiol 66:4022-4028.

108. Osorio CR and Klose KE (2000) A region of the transmembrane regulatory protein tox $\mathrm{R}$ that tethers the transcriptional activation domain to the cytoplasmic membrane displays wide divergence among Vibrio species. J Bacteriol 182:526-528.

109. Tamerius JD, Wise EK, Uejio CK, McCoy AL and Comrie AC (2007) Climate and human health: synthesizing environmental complexity and uncertainty. Stoch. Environ. Res. Risk Assess. On line first.

110.De Magny GC, Cazelles B and Guégan J-F (2006) Cholera threat to humans in Ghana is influenced by both global and regional climatic variability. EcoHealth 3(4):223-231.

111. Checkley W, Epstein LD, Gilman RH, Figueroa D, Cama RI, Patz JA and Black RE (2000) Effects of El Niño and ambient temperature on hospital admissions for diarrhoeal diseases in Peruvian children. Lancet 355:442-450.

112.Speelmon EC, Checkley W, Gilman RH, Patz J, Calderon M, Manga S (2000) Cholera incidence and El Niño related higher ambient temperature. JAMA 283(23): 3072-3073.

113.Simanjuntak $\mathrm{CH}$, Larasati $\mathrm{W}$, Arjoso S, Putri M, Lesmana $M$, Oyofo BA, Sukri N, Nurdin D, Kusumaningrum RP, Punjabi N, Subekti D, Djelantik S, Lubis A, Siregar $H$, Mas'Ud B, Abdi M, Sumardiati A, Wibisana S, Wanto H, Wan BS, Santoso W, Putra E, Sarumpaet S, Ma'Ani H, Lebron C, Soeparmanto SA, Campbell JR and Corwin AL (2001) Cholera in Indonesia in 1993-1999. Am J Trop Med Hyg 65:788-797.

114. Koelle K, Rodo X, Pascual M, Yunus M, Mostafa G (2005) Refractory periods and climate forcing in cholera dynamics. Nature 436:696-700. 
115. Hales S, de Wet N, Maindonald J, Woodward A (2002) Potential effect of population and climate changes on global distribution of dengue fever. The Lancet 360:830 834

116. Lieshout van $M$, Kovats RS, Livermore MTJ, Martens $P$ (2004) Climate change and malaria: analysis of the SRES climate and socio-economic scenarios. Global Environ. Change 14:87-99.

117. Kovats S, Campbell-Lendrum DH, Matthies F (2005) Climate change and human health: estimating avoidable deaths and disease. Risk Anal 25:1409-1418.

118. Wilcox BA and Colwell RR (2005) Emerging and reemerging infectious diseases: Biocomplexity as an interdisciplinary paradigm. EcoHealth 2:244-257.

119. McMichael AJ and Kovats RS (2000) Climate change and climate variability: adaptations to reduce adverse health impacts. Environ Monitor Assess 61:49-64.

120. Kovats RS, Campbell-Lendrum DH, Mc-Michael AJ, Woodward A and Cox JS (2001) Early effects of climate change: do they include changes in vector-borne diseases? Philos Trans R Soc London B 356:1057-1068.
121.Cottingham KL, Chiavelli DA, Taylor RK (2003) Environmental microbe and human pathogen: the ecology and microbiology of Vibrio cholerae. Frontiers in Ecology and the Environment 1(2):80-86.

122. McMichael AJ (2001) Global environmental change as "Risk Factor": can epidemiology cope? Am J Public Health 91(8):1172-1174.

Corresponding Author: Violeta Trinidad Pardío Sedas, Facultad de Medicina Veterinaria y Zootecnia, Universidad Veracruzana, Apartado Postal 1380, Veracruz, Veracruz, México CP. 91700, email: vpardio@yahoo.com.mx.

Conflict of Interests: The author declares that she has no conflict of interests. 